\title{
A case of pancreatic hamartoma pathologically confirmed after robot-assisted pancreaticoduodenectomy
}

\author{
Dong Hyun Shin ${ }^{1}$, Seoung Yoon Rho ${ }^{2,3}$, Ho Kyoung Hwang ${ }^{2,3}$, Woo Jung Lee ${ }^{2,3}$, and Chang Moo Kang ${ }^{2,3}$ \\ ${ }^{1}$ College of Medicine, Yonsei University, ${ }^{2}$ Division of Hepatobiliary and Pancreatic Surgery, Department of Surgery, \\ Yonsei University College of Medicine, ${ }^{3}$ Pancreatobiliary Cancer Center, Yonsei Cancer Center, Severance Hospital, \\ Seoul, Korea
}

\begin{abstract}
Pancreatic hamartoma is a rare benign tumor that can be easily misdiagnosed due to its rarity. Its diagnostic ambiguity demands surgical resection for confirmation. We reported a 54-year-old female patient with a pancreatic hamartoma that was pathologically confirmed after surgery, and we reviewed all the reported literature for adult pancreatic hamartomas. With the advancement of techniques for minimally invasive surgery, laparoscopic or robotic pancreatectomy can be safely performed on benign or low-grade malignant tumors in which the diagnosis is uncertain. (Ann Hepatobiliary Pancreat Surg 2019;23:286-290)
\end{abstract}

Key Words: Pancreatic harmatoma; Robotic pancreaticoduodenectomy; Minimally invasive surgery

\section{INTRODUCTION}

A hamartoma is a benign tumor-like malformation that resembles a neoplasm in the tissue of its origin. Although the etiology is not well known, it has been demonstrated that a hamartoma is composed of normal tissue elements at the affected site, and these tissues grow in a disorganized manner. ${ }^{1}$ Hamartomas can arise from different places in the body, and the lungs are the most common site. A pancreatic hamartoma is extremely rare and composes less than $1 \%$ of all hamartomas. ${ }^{2}$ Its rarity makes the pancreatic hamartoma difficult to differentiate from other benign or low-grade malignant tumors, and radiologic features are not well established. Thus, the confirmative diagnosis of a pancreatic hamartoma is made by histopathological and immunohistochemical results after surgical resection. ${ }^{3}$

Although the safety of minimally invasive pancreaticoduodenectomy (MI-PD) is still controversial, accumulating experience suggests that MI-PD is technically feasible and safe. Furthermore, MI-PD can be one of the potential options in treating patients with benign or low-grade ma- lignant pancreatic tumors in consideration of their longterm survival.

In this report, we presented a case of pancreatic hamartoma that was pathologically confirmed after minimally invasive pancreaticoduodenectomy and also reviewed the literature relevant to pancreatic hamartomas.

\section{CASE}

\section{Clinical presentation}

A 54-year-old female patient visited the outpatient clinic in our institute in November 2017 due to an incidentally found mass in the head of the pancreas during a routine medical check-up. She had a generally goodlooking appearance and did not describe any symptoms. Her body weight was $48.0 \mathrm{~kg}$, and body mass index was $18.99 \mathrm{~kg} / \mathrm{m}^{2}$. Physical examination did not show any abnormalities. Her past medical history included a uterine myomectomy in 2010, and she had no history of pancreatitis. She was not an alcoholic.

Received: November 22, 2018; Revised: April 25, 2019; Accepted: April 30, 2019

Corresponding author: Chang Moo Kang

Division of Hepatobiliary and Pancreatic Surgery, Department of Surgery, Yonsei University College of Medicine, 50-1 Yonsei-ro, Seodaemun-gu, Seoul 03722, Korea

Tel: +82-2-2228-2100, Fax: +82-2-313-8289, E-mail: cmkang@yuhs.ac

Copyright (C) 2019 by The Korean Association of Hepato-Biliary-Pancreatic Surgery

This is an Open Access article distributed under the terms of the Creative Commons Attribution Non-Commercial License (http://creativecommons.org/ licenses/by-nc/4.0) which permits unrestricted non-commercial use, distribution, and reproduction in any medium, provided the original work is properly cited. Annals of Hepato-Biliary-Pancreatic Surgery - pISSN: 2508-5778 - elSSN: 2508-5859 


\section{Preoperative evaluation}

Routine blood laboratory examinations, including serum amylase and lipase, were within the normal ranges. The level of carbohydrate antigen 19-9 and carcinoembryonic antigen were $24.1 \mathrm{U} / \mathrm{ml}$ and $1.77 \mathrm{ng} / \mathrm{ml}$, respectively. A contrast enhanced abdominal computed tomography (CT) scan revealed an approximately $2.7 \mathrm{~cm}$ sized low-attenuating mass in the head of the pancreas, without pancreatic duct dilatation (Fig. 1A), and peripheral enhancement on the portal venous phase (Fig. 1B). Gallium (Ga)-68 DOTA-TOC and FDG PET/CT were performed for further evaluation, and there was no discernible Ga-68 DOTATOC and FDG uptake in the pancreatic head (Fig. 1C, D).

\section{Operative finding}

Considering the potential long-term survival of a patient with a preoperative diagnosis of a pancreatic solid pseudopapillary tumor or a neuroendocrine tumor, we performed a robot-assisted pylorus-preserving PD (laparoscopic resection followed by robotic reconstruction; pancreatojejunostomy and hepaticojejunostomy). The duodenojejunostomy was performed through a small, extended, periumbilical wound from which the surgical specimens were removed. It was noted that the remnant pancreas was soft, the pancreatic duct was $1 \mathrm{~mm}$, and the resected bile duct size was $8 \mathrm{~mm}$ in diameter. The operation time was 300 minutes. Estimated blood loss was $200 \mathrm{ml}$, and no intraoperative transfusion was noted.

\section{Pathological examination}

Macroscopically, the cut surface of the pancreas showed an ill-defined, whitish, firm mass. On multiple serial sections, the cut surface showed a well-defined, whitish, lobular, firm mass $(2.2 \times 1.7 \mathrm{~cm}$, Fig. 2A). Microscopically, well-defined pancreatic acini and ductal elements were noted (Fig. 2B). The immunohistochemical stain revealed negative results for $\mathrm{CD} 34$ and $\mathrm{C}$-kit in the tumor cells (Fig. 2C, D). Thus, the mass was confirmed as a pancreatic hamartoma

\section{Postoperative course and follow-up}

There were no clinically-relevant postoperative complications, which demonstrated POPF grade A (The amylase and lipase levels of the peritoneal fluid were $363 \mathrm{U} / \mathrm{L}$ and $822 \mathrm{U} / \mathrm{L}$, and those of serum were $70 \mathrm{U} / \mathrm{L}$ and $69 \mathrm{U} / \mathrm{L}$, respectively, on postoperative day 3 ). The surgical drains were removed on postoperative day five. The patient was discharged on postoperative day 10. Six months after surgery, an abdominopelvic CT demonstrated no evidence of local tumor recurrence or distant metastasis.
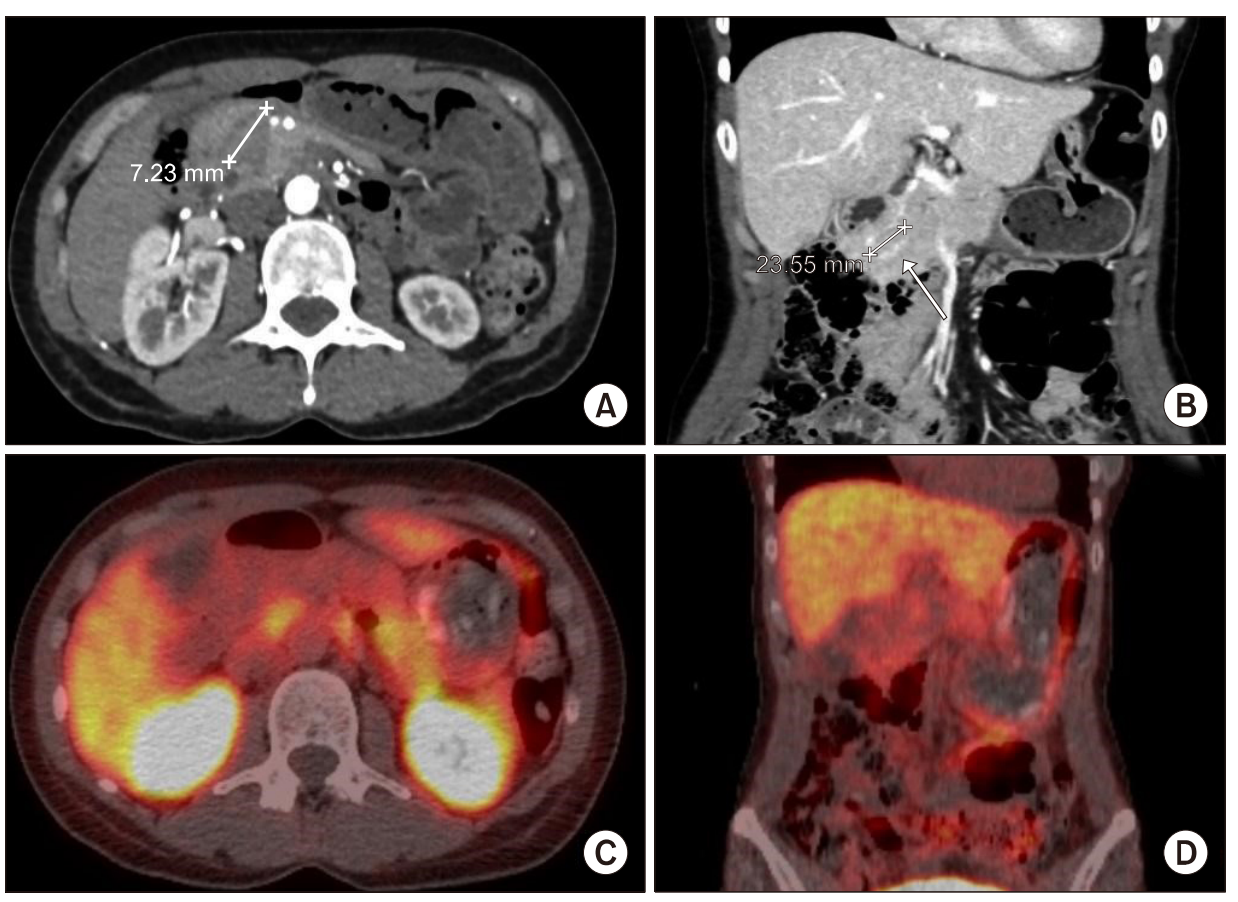

Fig. 1. (A) Preoperative computed tomography (CT) showed a $2.7 \mathrm{~cm}$-sized low-attenuating mass (white arrow) in pancreatic head. (B) Mass showed peripheral enhancement on the portal venous phase. (C) PETCT showed a tumor with increased FDG uptake. (D) PET$\mathrm{CT}$ in coronal sectional view. 

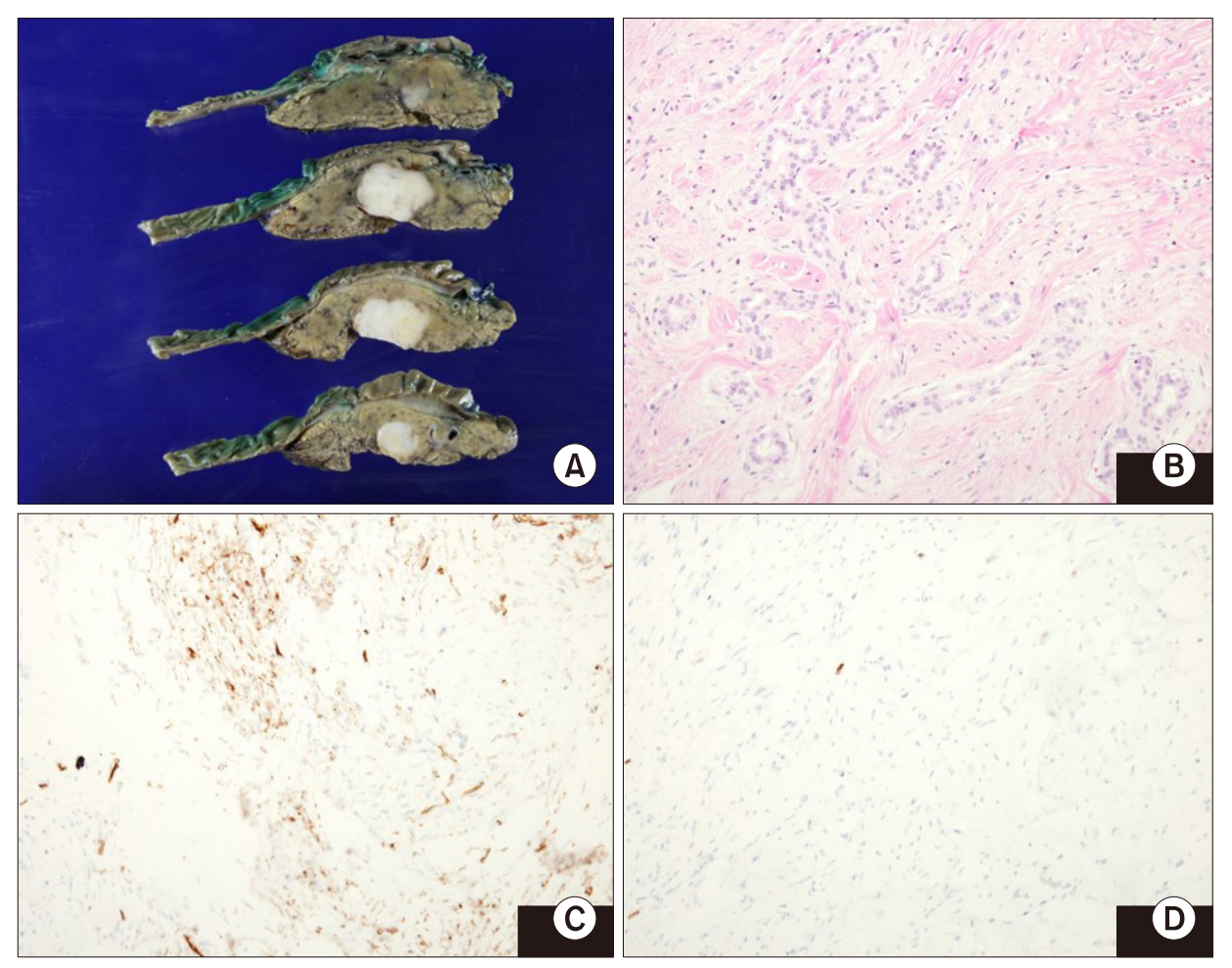

Fig. 2. (A) Well-defined, whitish, lobular, firm mass $(2.2 \times 1.7 \mathrm{~cm})$. (B) $(\mathrm{H} \& \mathrm{E} \times 100)$ Well-defined pancreatic acini and ductal elements. (C) $(\times 100)$ Negative for CD 34. (D) $(\times 100)$ Negative for C-kit.

\section{DISCUSSION}

\section{Literature review}

Twenty-five patients with pancreatic hamartoma have been reported ${ }^{1-17}$, including the present case. Excluding four pediatric patients, ${ }^{18} 21$ adult patients with pancreatic hamartoma are summarized in Table 1.

The patients were composed of nine males and $12 \mathrm{fe}$ males, and the average age was $52.6 \pm 14.4$ years, although there is one reported case in a newborn. Nine patients (42.9\%) were asymptomatic, and more than half of the patients $(57.1 \%)$ in the literature presented with symptoms, such as abdominal pain or discomfort. Symptomatic patients were associated with age $(61.4 \pm 11.4$ years vs. $45.9 \pm$ 12.9 years, $p=0.010)$, not tumor size $(2.5 \pm 0.7 \mathrm{~cm}$ vs. $3.8 \pm$ $3.1 \mathrm{~cm}, p=0.185$ ). Most tumors were located in the head region of the pancreas (head+neck, 15 out of 21, $71.4 \%)^{2,4-7,9,11-14}$. The average tumor size was $3.2 \pm 2.4 \mathrm{~cm}$ in diameter. Pancreaticoduodenectomy was performed in 13 patients $(6.9 \%)$, distal pancreatectomy in four patients (19\%), and local resection including central pancreatectomy in 3 patients $(14.3 \%)$. All of the reported cases did not have a preoperative diagnosis. The most frequent diagnosis was neuroendocrine tumor or solid pseudopapillary neoplasm of the pancreas, suggesting the mass appeared more like a benign or low-grade malignant tumor rather than an aggressive malignant pathology. Thus, surgeries were essential for the confirmative diagnoses. Pancreaticoduodenectomy for a mass in the pancreatic head and distal pancreatectomy or local resection for a mass in another area of the pancreas were performe $d$ (12/1/1 vs. $1 / 3 / 2, p=0.009$, Fisher's exact test), and only two cases utilized robotic surgeries ${ }^{3}$, including the present case. The pathologic types of pancreatic hamartoma are solid and solid/cystic, and these can appear on an image as a nodule or a nodule with cystic components, respectively. Old age was associated with the solid type of hamartoma $(60.1 \pm 9.9$ years vs. $44.7 \pm 14.5$ years, $p=0.016$ ). There were no reported cases of recurrence.

On laboratory examination, most biochemical markers, including serum amylase, lipase and tumor markers, show normal levels in patients with pancreatic hamartomas. The tumor appears as a well-demarcated hypodense mass (relative to the pancreas) on a pre-contrast CT image and shows heterogeneously-progressive enhancement in the delayed phase. Although such a presentation resembles a benign tumor, malignant tumors cannot be excluded. Needle aspiration biopsy is not helpful, because it is usually only composed of normal cells: acinar, ductal, and islet cells. The location of the mass and the patient's nonspecific 
Table 1. Reported adult pancreatic hamartoma cases

\begin{tabular}{|c|c|c|c|c|c|c|c|c|}
\hline References & Year & $\begin{array}{l}\text { Age/ } \\
\text { gender }\end{array}$ & Symptom & Location & $\begin{array}{l}\text { Size } \\
(\mathrm{cm})\end{array}$ & $\begin{array}{l}\text { Preoperative } \\
\text { diagnosis }\end{array}$ & Surgery & $\begin{array}{l}\text { Pathologic } \\
\text { type }\end{array}$ \\
\hline Izbicki et al. ${ }^{4}$ & 1994 & $25 / \mathrm{M}$ & $\begin{array}{l}\text { Postprandial } \\
\text { epigastric pain }\end{array}$ & Head & 10.6 & $\begin{array}{l}\text { Hypervascular } \\
\text { tumor }\end{array}$ & PD (partial) & $\mathrm{S} / \mathrm{C}$ \\
\hline $\mathrm{Wu}$ et $\mathrm{al}^{5}$ & 1998 & $39 / \mathrm{M}$ & $\begin{array}{l}\text { Prandial epigastric } \\
\text { pain, weight loss }\end{array}$ & Head & 8.0 & $\begin{array}{l}\text { Pancreatic } \\
\text { pseudocyst }\end{array}$ & Whipple & NR \\
\hline \multirow[t]{2}{*}{ McFaul et al. ${ }^{6}$} & 2004 & $29 / \mathrm{M}$ & $\begin{array}{l}\text { Abdominal pain, } \\
\text { weight loss }\end{array}$ & Head & 1.0 & NET & PPPD & NR \\
\hline & & $62 / \mathrm{M}$ & $\begin{array}{l}\text { Abdominal pain, } \\
\text { weight loss }\end{array}$ & Head & 3.5 & NR & Whipple & NR \\
\hline \multirow[t]{2}{*}{ Pauser et al. ${ }^{7}$} & 2005 & $36 / \mathrm{F}$ & Epigastric pain & Head & 7.0 & NR & Whipple & $\mathrm{S} / \mathrm{C}$ \\
\hline & & $55 / \mathrm{F}$ & Abdominal pain & Neck & 3.0 & NR & DP & $\mathrm{S} / \mathrm{C}$ \\
\hline \multirow[t]{2}{*}{ Pauser et al. ${ }^{8}$} & 2005 & $51 / \mathrm{M}$ & Asymptomatic & Tail & 3.0 & $\begin{array}{l}\text { Unclear nature } \\
\text { of tumor }\end{array}$ & LR & $\mathrm{S}$ \\
\hline & & $54 / \mathrm{F}$ & Abdominal discomfort & Body & 2.0 & NR & DP & S \\
\hline Nagata et al. ${ }^{1}$ & 2007 & $58 / \mathrm{F}$ & Asymptomatic & Body & 1.9 & NET & DP & S \\
\hline Sampelean et al. ${ }^{9}$ & 2009 & $46 / \mathrm{M}$ & $\begin{array}{l}\text { Epigastric pain, } \\
\text { weight loss }\end{array}$ & Head & 0.9 & NR & PD & S \\
\hline Durczynski et al. ${ }^{10}$ & 2011 & 69/M & Asymptomatic & Body & 2.2 & Solid tumor & LR & S \\
\hline Kawakami et al. ${ }^{11}$ & 2012 & $78 / \mathrm{M}$ & Asymptomatic & Head & 1.8 & Pancreatic cancer & $\mathrm{PD}$ & S \\
\hline Kim et al. $^{2}$ & 2012 & $52 / \mathrm{F}$ & $\begin{array}{l}\text { Postprandial } \\
\text { abdominal discomfort }\end{array}$ & Head & 2.2 & $\begin{array}{l}\text { SPT or serous } \\
\text { cystic neoplasm }\end{array}$ & PPPD & $\mathrm{S} / \mathrm{C}$ \\
\hline Inoue et al. ${ }^{12}$ & 2014 & $65 / \mathrm{F}$ & Jaundice & Head & 4.0 & NR & $\mathrm{PD}$ & S \\
\hline Addeo et al. ${ }^{3}$ & 2014 & $61 / \mathrm{F}$ & Asymptomatic & Body & 2.4 & NR & Robotic DP & S \\
\hline Zhang et al. ${ }^{13}$ & 2016 & $53 / \mathrm{F}$ & $\begin{array}{l}\text { Abdominal pain, } \\
\text { weight loss }\end{array}$ & Head & 2.2 & $\begin{array}{l}\text { Pancreatic space- } \\
\text { occupying lesion }\end{array}$ & $\mathrm{PD}$ & S \\
\hline Matsushita et al. ${ }^{14}$ & 2016 & $68 / \mathrm{M}$ & Asymptomatic & Head & 4.0 & $\begin{array}{l}\text { Lipoma, dermoid } \\
\text { cyst, or other rare } \\
\text { benign tumor }\end{array}$ & PPPD & $\mathrm{S} / \mathrm{C}$ \\
\hline Nagano et al. ${ }^{15}$ & 2017 & $72 / \mathrm{F}$ & Asymptomatic & Head & 2.0 & NR & PPPD & S \\
\hline Nahm et al. ${ }^{16}$ & 2019 & $42 / \mathrm{F}$ & Abdominal pain & Neck & 2.8 & SPT & $\mathrm{CP}$ & $\mathrm{S} / \mathrm{C}$ \\
\hline Han et al. ${ }^{17}$ & 2018 & $35 / \mathrm{F}$ & $\begin{array}{l}\text { Recurrent } \\
\text { hypoglycemic events } \\
\text { on hunger }\end{array}$ & Tail & 1.0 & $\begin{array}{l}\text { Hypervascular solid } \\
\text { tumor (NET) }\end{array}$ & DP & $\mathrm{S} / \mathrm{C}$ \\
\hline Present case & 2017 & $54 / \mathrm{F}$ & Asymptomatic & Head & 2.2 & SPT or NET & $\begin{array}{l}\text { Robot assisted } \\
\text { PPPD }\end{array}$ & S \\
\hline
\end{tabular}

NR, not reported; NET, neuroendocrine tumor; SPT, solid pseudopapillary tumor; PD, pancreaticoduodenectomy; PPPD, pylorus-preserving PD; LR, local resection; DP, distal pancreatectomy; CP, central pancreatectomy; S/C, solid and cystic; S, Solid

symptoms make it impossible to exclude malignant tumors in the differential diagnosis. Above all, the rare incidence of pancreatic hamartomas makes preoperative diagnosis difficult. Due to diagnostic uncertainty, operations were performed in all reported cases of pancreatic hamartomas, which were indistinguishable from malignant tumors or low-grade malignant tumors. In the presence of these preoperative diagnostic ambiguities, physicians must consider the possibility of pancreatic hamartoma given the evidence found in the literature review.

Although surgery is inevitable for diagnostic confirmation, it is meaningful to consider other benign tumors or low-grade malignant tumors in the preoperative diag- nosis. Unlike patients with pancreatic cancer, patients with pancreatic hamartomas and other benign tumors show longterm survival, and minimally invasive approaches that consider patient quality of life are most appropriate when selecting the surgery. As in this case, the absence of obstructive jaundice and obstructive pancreatitis when the pancreaticoduodenectomy is divided into the resection stage and the reconstruction stage suggests that the minimally invasive approach is suitable in the resection stage. However, when reconstructing the remaining pancreas and bile duct, handling a soft pancreas with a small pancreatic duct and small-diameter bile duct would be technically demanding. ${ }^{19}$ Therefore, in this case, after laparoscopic re- 
section of the pancreatic head, reconstruction was safely and efficiently performed by taking advantage of a robot. In recent studies, the safety and efficacy of minimally invasive pancreaticoduodenectomy (MI-PD) has been well documented, and it may be an effective treatment for wellselected benign and low-grade malignant tumors. ${ }^{20}$ The development of a systematic surgical education program and management of its quality are important for the establishment of safe MI-PD surgeries.

\section{ACKNOWLEDGEMENTS}

This case was demonstrated in international robotic surgery live 2017 (Severance Hospital, Seoul, Korea) on December 15, 2107.

\section{REFERENCES}

1. Nagata S, Yamaguchi K, Inoue T, Yamaguchi H, Ito T, Gibo J, et al. Solid pancreatic hamartoma. Pathol Int 2007;57:276-280.

2. Kim HH, Cho CK, Hur YH, Koh YS, Kim JC, Kim HJ, et al. Pancreatic hamartoma diagnosed after surgical resection. J Korean Surg Soc 2012;83:330-334.

3. Addeo P, Tudor G, Oussoultzoglou E, Averous G, Bachellier P. Pancreatic hamartoma. Surgery 2014;156:1284-1285.

4. Izbicki JR, Knoefel WT, Müller-Höcker J, Mandelkow HK. Pancreatic hamartoma: a benign tumor of the pancreas. Am J Gastroenterol 1994;89:1261-1262.

5. Wu SS, Vargas HI, French SW. Pancreatic hamartoma with Langerhans cell histiocytosis in a draining lymph node. Histopathology 1998;33:485-487.

6. McFaul CD, Vitone LJ, Campbell F, Azadeh B, Hughes ML, Garvey CJ, et al. Pancreatic hamartoma. Pancreatology 2004;4: 533-537; discussion 537-538.

7. Pauser U, Kosmahl M, Kruslin B, Klimstra DS, Klöppel G. Pancreatic solid and cystic hamartoma in adults: characterization of a new tumorous lesion. Am J Surg Pathol 2005;29:797-800.

8. Pauser U, da Silva MT, Placke J, Klimstra DS, Klöppel G.
Cellular hamartoma resembling gastrointestinal stromal tumor: a solid tumor of the pancreas expressing c-kit (CD117). Mod Pathol 2005;18:1211-1216.

9. Sampelean D, Adam M, Muntean V, Hanescu B, Domsa I. Pancreatic hamartoma and SAPHO syndrome: a case report. J Gastrointestin Liver Dis 2009;18:483-486.

10. Durczynski A, Wiszniewski M, Olejniczak W, Polkowski M, Sporny S, Strzelczyk J. Asymptomatic solid pancreatic hamartoma. Arch Med Sci 2011;7:1082-1084.

11. Kawakami F, Shimizu M, Yamaguchi H, Hara S, Matsumoto I, $\mathrm{Ku} \mathrm{Y}$, et al. Multiple solid pancreatic hamartomas: a case report and review of the literature. World J Gastrointest Oncol 2012;4: 202-206.

12. Inoue $H$, Tameda $M$, Yamada $R$, Tano $S$, Kasturahara $M$, Hamada Y, et al. Pancreatic hamartoma: a rare cause of obstructive jaundice. Endoscopy 2014;46 Suppl 1 UCTN:E157-E158.

13. Zhang J, Wang H, Tang X, Jiang Q, Wang C. Pancreatic hamartoma, a rare benign disease of the pancreas: a case report. Oncol Lett 2016;11:3925-3928.

14. Matsushita D, Kurahara H, Mataki Y, Maemura K, Higashi M, Iino S, et al. Pancreatic hamartoma: a case report and literature review. BMC Gastroenterol 2016;16:3.

15. Nagano H, Nakajo M, Fukukura Y, Kajiya Y, Tani A, Tanaka $\mathrm{S}$, et al. A small pancreatic hamartoma with an obstruction of the main pancreatic duct and avid FDG uptake mimicking a malignant pancreatic tumor: a systematic case review. BMC Gastroenterol 2017; 17:146.

16. Nahm CB, Najdawi F, Reagh J, Kaufman A, Mittal A, Gill AJ, et al. Pancreatic hamartoma: a sheep in wolf's clothing. ANZ J Surg 2019;89:E265-E267.

17. Han YE, Park BJ, Sung DJ, Kim MJ, Han NY, Sim KC, et al. Computed tomography and magnetic resonance imaging findings of pancreatic hamartoma: a case report and literature review. Clin Imaging 2018;52:32-35.

18. Sueyoshi R, Okazaki T, Lane GJ, Arakawa A, Yao T, Yamataka A. Multicystic adenomatoid pancreatic hamartoma in a child: case report and literature review. Int J Surg Case Rep 2013;4: 98-100.

19. Kang CM, Lee SH, Chung MJ, Hwang HK, Lee WJ. Laparoscopic pancreatic reconstruction technique following laparoscopic pancreaticoduodenectomy. J Hepatobiliary Pancreat Sci 2015;22: 202-210.

20. Magge D, Zureikat A, Hogg M, Zeh HJ 3rd. Minimally invasive approaches to pancreatic surgery. Surg Oncol Clin N Am 2016; 25:273-286. 